\author{
주남저수지 유역의 오염원과 수질변동에 따른 \\ 식물플랑크톤 군집 \\ 이혜진 · 서정관 ${ }^{*}$ 정현기 · 탁보미· 이재관 \\ 국립환경과학원 낙동강물환경연구소 \\ (2010년 10월 5일 접수; 2010년 10월 28일 수정; 2010년 11월 24일 채택)
}

\title{
Phytoplankton Community in Junam Reservoir by Pollution Sources, Loads and Water Quality
}

\author{
Hae-Jin Lee, Jung-Kwan Seo ${ }^{*}$, Hyun-Ki Jeong, Bo-Mi Tak, Jae-Kwan Lee \\ Nakdong River Environment Research Center, NIER, Gyeongbuk 717-873, Korea \\ (Manuscript received 5 October, 2010; revised 28 October, 2010; accepted 24 November, 2010)
}

\begin{abstract}
This study presented seasonal changes of the phytoplankton community in Junam reservoir by pollution and water quality of the lake. The water storage of the reservoir is 5.3 million ton, most of which are being utilized for agricultural, industrial and residential purposes. The annual precipitation during the investigation period was $1,868.9$ $\mathrm{mm}$, increasing by $20 \%$ from the average annual level of $1,506.7 \mathrm{~mm}$ in 2009 . The annual average water storage was $57.3 \%$. It decreased during agricultural season and then increased again after monsoon rainfall. The loads of BOD were $3,799 \mathrm{kgday}^{-1}$, and $81 \%$ of them came from livestock and household. The TN and TP loads were $1,164 \mathrm{kgday}^{-1}$ and $170 \mathrm{kgday}^{-1}$, respectively, and $76 \%$ of them came from livestock. We assessed water quality of the Junam reservoir using 17 variables. According to the result, the reservoir met the fourth grade, meaning slightly bad, because of high concentration of COD, SS and chlorophyll-a. Eutrophication assessment was conducted by revised Carlson's Index (TSIm, Aizaki), and it was found that the entire lake was eutrophicated with high chlorophyll-a concentration all through the year, except during February to April and in July. A total of 76 phytoplankton species were identified from the samples. Among them, the largest number of species were Chlorophyceae with 33 species(43.4\%), followed by Bacilliophyceae with 27 species(35.5\%), Cyanophyceae with 8 species(10.5\%), and Cryptophyceae with species(10.5\%). The total cell number of phytoplankton was the highest in October $\left(7,884\right.$ cells $\left.\mathrm{mL}^{-1}\right)$ among Cyanophyceae and Bacilliophyceae. The seasonal succession of Chlorophyceae (Chlamydomonas spp.), Cyanophyceae(Microcystis aeruginosa) and Cryptophyceae(Rhodomonas spp.) was observed during January to May, July to September and October to December respectively.
\end{abstract}

Key Words : Pollution loads, Water quality, Phytoplankton, Eutrophication, Seasonal succession

\footnotetext{
${ }^{*}$ Corresponding author : Jung-Kwan Seo, Nakdong River Environment Research Center, NIER, Gyeongbuk 717-873, Korea

Phone: +82-54-950-9730

E mail: jkseo2001@korea.kr
}

\author{
1. 서 론 \\ 우리나라에 분포하고 있는 대부분의 호소는 인공 \\ 호이며 주로 농업이나 수자원 공급을 위한 용도로 이 \\ 용되고 있으며, 상대적으로 규모가 작은 호소들이 주
}


를 이루고 있다. 이 중 평균 수심 $10 \mathrm{~m}$ 이하의 소규모 농업용 저수지가 $95 \%$ 이상을 차지하고 있다. 또한 이 들 소규모 저수지의 $50 \%$ 이상이 50 년 이상 되어 시간 의 경과에 따른 인간 활동에 의해 인근으로부터 토사 나 오염물질의 유입량의 증가로 수질 오염 가능성이 매우 높다(윤 등, 2007). 뿐만 아니라 우리나라의 기 후 특성상 계절에 따라 강우량이 크게 변하는 몬순기 후 지역에 속해 있어, 여름철 집중 강우로 인한 하천 유량의 변화, 외부 오염원의 유입 등은 중소규모 호소 의 관리를 필요로 한다.

본 연구 대상 호소인 주남저수지는 행정구역상 경 상남도 창원시 동읍(N $\left.35^{\circ} 18^{\prime} 46^{\prime \prime} \mathrm{E} 128^{\circ} 39^{\prime} 55^{\prime \prime}\right)$ 에 위치하며, 금병산 $(271.8 \mathrm{~m})$, 정병산 $(566.7 \mathrm{~m})$, 구룡산 $(433.5 \mathrm{~m})$ 및 백월산 $(300 \mathrm{~m})$ 의 지맥 등을 분수령으로 하여 홍수시에 집수된 물이 낙동강으로 유입되는 것 을 막기 위해 형성된 늪지대였던 지역을 1920 년에 농 업용수 공급을 위해 둑을 만들면서 일정한 수위를 가 지게 된 오래된 인공호이다(함과 손, 1998). 주남(3.7 $\mathrm{km})$, 산남 $(0.75 \mathrm{~km})$ 및 동판 $(0.5 \mathrm{~km})$ 의 3 개의 저수지가 수로로 연결되어 낙동강 수위에 따라 변동하며 연중 평균 수심 $0.8 \mathrm{~m}$, 만수면적 $3.65 \mathrm{~km}$, 유효저수량은 5,302 천 톤의 수심이 얕은 소규모 저수지에 속한다. 주남저수지는 낙동강 물을 저수하여 창원시 동읍과 대산면 일대 $18 \mathrm{~km}^{2}$ 의 농경지에 농업용수를 공급하는 것이 주기능이며 여름철 집중 강우시 만수위가 되면, 마산, 진해 및 창원 등지에 송수관로를 통해 공업용수 를 공급하고, 동북면 일대의 농경지에 농업용수를 공 급하는 등 수자원 공급면에서 중요한 역할을 한다. 또 한 지리적으로 을숙도와 우포늪 중간지점에 위치하고 있어 우리나라 주요한 철새 서식지 중 하나로서 알려 져 있으며, 최근에는 생태적 가치가 높은 습지로서의 기능과 역할을 가지는 것으로 알려져 있다(이와 안, 2009).

그러나 지난 10 년간 주남저수지에 대한 조사 연구 는 철새도래(박과 이, 2009; 유와 황, 1994; 함과 손, 1998; 함 등, 1999), 수생생물군(박, 1995;이 등, 1994; 이 등, 1997;조와 곽, 1998) 또는 이화학적 수질(양, 2005; 이와 안, 2009) 및 영양상태 등 분야별로 이루 어지긴 하였으나, 장기간의 지속적인 연구는 부족한 실정이다. 따라서 본 연구에서는 주남저수지 유역의
오염원, 오염부하량을 조사하고, 호소를 대표하는 지 점인 호소 중앙부를 대상으로 매월 수질 및 동식물플 랑크톤 분포 특성을 파악하여 향후 주남저수지의 지 속적이고 효율적인 관리를 위한 기초 자료를 제시하 고자 한다.

\section{2. 재료 및 방법}

\section{1. 조사지점 및 조사기간}

본 연구는 낙동강 중하류에 위치한 주남저수지를 대상으로 하였으며 조사지점과 조사수심은 호소환경 조사지침(환경부, 2001)에 따라 선정하였다. 조사지 점은 Fig. 1 과 같이 호내 중앙부를 대표 지점하였으며, 조사기간은 2009년 1월부터 12월까지 매월 일정한 기 간에 호내 수질이 안정되고 대표적인 상태라고 판단 된 때 표층수 시료를 채수하였다. 호수 유역의 강우량 과 저수율 자료는 기상청(http://www.kma.go.kr)과 한국 농촌공사 홈페이지(http://www.ekr.or.kr)의 일 자료를 사용하였다.

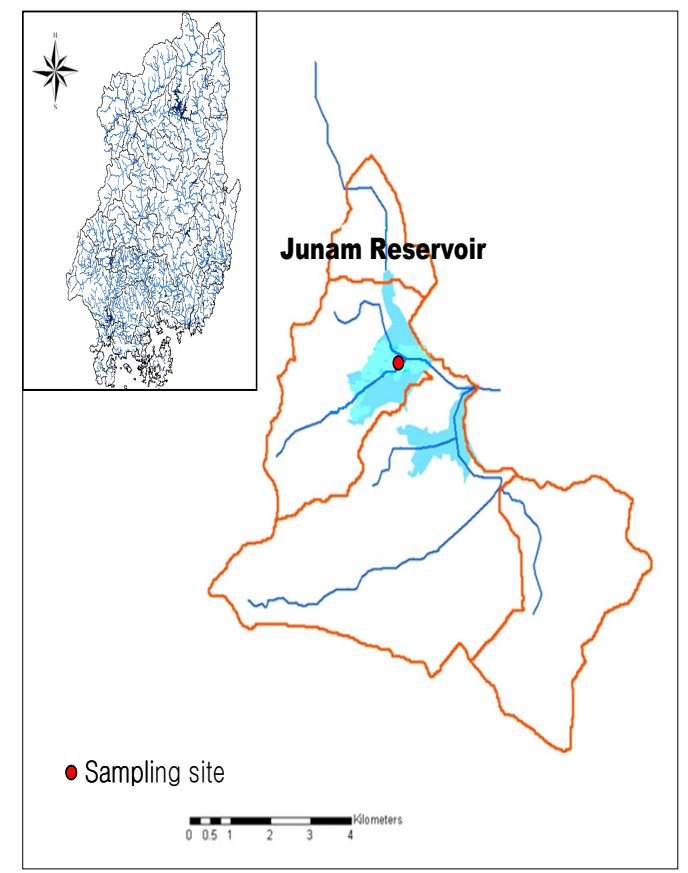

Fig. 1. Map showing Junam reservoir watershed and the survey site. 


\section{2. 호소유역 오염원 및 오염부하량}

본 연구에서는 ArcGIS 기반의 수문해석 프로그램 인 Arc Hydrotool을 이용하여 호소로 유입하는 주요 지천을 중심으로 호소 상류 유역을 소유역으로 분할 한 후, 각 유역에 해당하는 행정구역을 추출하고 유역 내 포함되는 행정구역 점유율을 적용하여 오염원을 조사하였다(Fig. 2). 주남저수지 유역의 오염부하량 산정은 전국 오염원 조사자료(환경부, 2007)를 이용하 여 “수계오염총량관리지침”(국립환경과학원, 2007)에 서 제시한 부하량 산정방법과 원단위를 적용하여 유 역 내 발생부하량과 배출부하량을 산정하였다.

\section{3. 호소수질, 부영양화도}

수질조사항목 중 수온, 수소이온농도 $(\mathrm{pH})$, 용존산소 량(Dissolved oxygen, DO), 전기전도도(Conductivity, $\mathrm{EC})$ 는 휴대용 수질자동측정기(YSI 556MPS)를 이용 하여 현장에서 측정하였으며, 투명도는 투명도판(지름 $20 \mathrm{~cm}$, 백색/흑색 원판)으로 측정하였다. 실험실 분석 항목은 현장 시료를 냉암소에서 보관하여 가능한 한 빨 리 실험실로 옮긴 후, 생화학적산소요구량(Biochemical Oxygen Demand, BOD), 화학적산소요구량(Chemical Oxygen Demand, COD), 부유물질(Suspended Solids, $\mathrm{SS}$ ), 클로로필 a (Chlorophyll-a), 총대장균군수(Total Coliforms), 분원성 대장균군수(Fecal Coliforms), 총 질소(Total Nitrogen, TN), 총인(Total Phosphorus,
$\mathrm{TP}$ ), 암모니아성 질소(Ammonium Nitrogen, $\mathrm{NH}_{3}-\mathrm{N}$ ), 질산성질소(Nitrate Nitrogen, $\mathrm{NO}_{3}-\mathrm{N}$ ), 인산염인 (Phosphate Phosphorus, $\mathrm{PO}_{4}-\mathrm{P}$ )는 수질오염공정시헙 방법에 준하되 필요한 경우 국제적으로 통용되고 있 는 표준시험방법(Standard methods, 2005)에 따라 분 석하였다. 주남저수지의 영양상태 분석은 조사기간 동안 측정된 자료 중 클로로필 a 농도와 총인 농도를 이용하여 부영양화 단계를 수정 Carlson 지수인 TSIm(Aizaki, 1981) 기준으로 산정하였고, 산정된 지 수가 40 미만이면 빈영양호, 40 50이면 중영양호, 50 을 초과하면 부영양호로 구분하였다.

\section{4. 식물플랑크톤 군집}

식물플랑크톤을 분석하기 위해 현장에서 채취한 정량시료를 Lugol 용액으로 고정하고 실험실로 옮겨 48 시간 이상 침강시킨 후 상등액을 제거하고 5 배 이 상 농축하였다. 농축된 시료 $1 \mathrm{~mL}$ 을 정량 분석용 Sedgwick Rafter 격자 슬라이드에 옮긴 후 10 분 이상 침전시킨 다음 광학현미경(Zeiss, Axioskop, Germany) 을 이용하여 200 배 1,000 배율로 검경하면서 종별로 동정한 후 세포수를 계수하고 현존량은 단위부피 $(\mathrm{mL})$ 당 세포수로 산출하였다. 식물플랑크톤의 종 동정은 한국담수조류도감(정, 1993)과 일본 담수조류도감 (Masaru, 1977) 등에 따라 실시하였다. 식물플랑크톤 의 군집 구조의 특성을 파악하기 위하여 우점도 지수

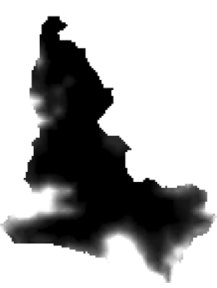

(a) Hydrological DEM

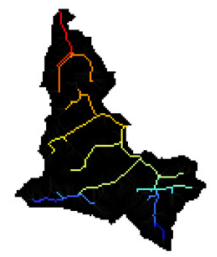

(d) Channel network

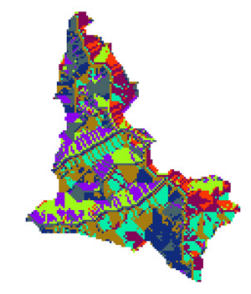

(b) Flow Direction

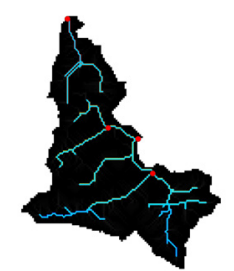

(e) Runoff Point

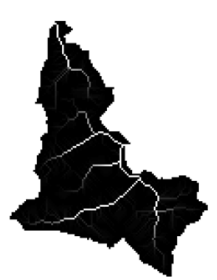

(c) Flow Accumulation

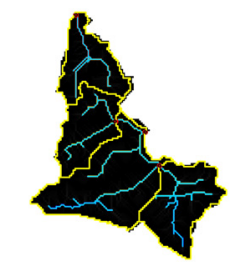

(f) Catchment Division

Fig. 2. Watershed delineating by the ArcHydrotool. 
(Dominance index)는 Simpson(1949)의 우점도 지수 (DI)를 사용하였고, 종 다양도 지수는 Shannon and Weaver(1963)의 공식 $\left(\mathrm{H}^{\prime}\right)$ 를 이용하여 월별 출현 개체 군을 분석하였다.

- Dominance Index, DI : $\quad \lambda=S U M \frac{N i^{x}(N i-1)}{N^{x}(N-1)}$

- Diversity index, $\mathrm{H}: \quad H^{\prime}=-\operatorname{SUM}\left[P i^{x} \log _{e}(P i)\right]$

(N: 개체군 총 개체수(total individuals), Pi: 총 출현개체 수에 대한 $\mathrm{i}$ 종의 개체수 비율)

\section{3. 결과 및 고찰}

\section{1. 기상 및 수리수문}

주남저수지의 수질변화와 식물플랑크톤 천이양상 에 직접적인 영향을 주는 기온, 강우량 등 기상요인은 Fig. 3에 나타내었고, 수리수문 특성을 보여주는 월별

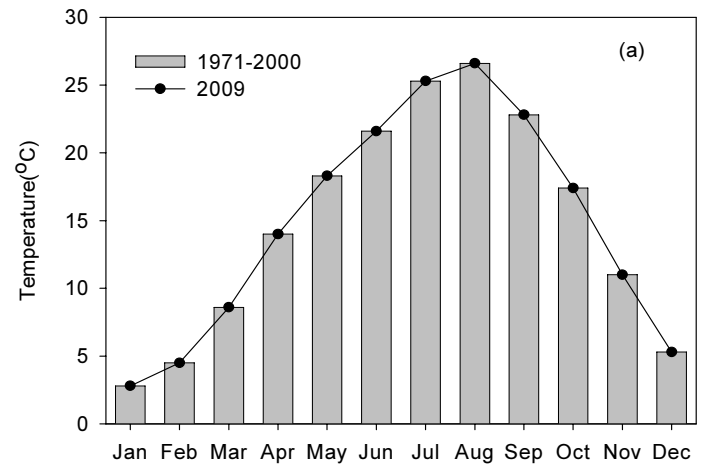

저수율은 Fig. 4에 제시하였다. 2009년 1월부터 12월 까지 유역 내 월별 평균기온은 $2.3 \sim 25.3{ }^{\circ} \mathrm{C}$ 로 연중 최 저기온은 1 월에 $-9.3{ }^{\circ} \mathrm{C}$, 최고기온은 8 월에 $33.7^{\circ} \mathrm{C}$ 를 나타내었다. 총 강우량은 $1,865.9 \mathrm{~mm}$ 로 평년(1,503.7 $\mathrm{mm})$ 에 비하여 $20 \%$ 증가하였다. 조사기간 중 6 8월의 강우량이 $1,247.0 \mathrm{~mm}$ 로 연간 총 강우량의 $70 \%$ 가 집중 되었고, 봄과 가을, 겨울에는 강우량이 매우 적었다. 월별로는 7월의 총강우량이 $818.6 \mathrm{~mm}$ 으로 평년(293.7 $\mathrm{mm})$ 에 비해 2 배 이상으로 증가하여 우리나라 몬순 강우 패턴을 보였다. 연평균 저수율은 $57.3 \%$ 로 갈수기인 2 월에 $40 \%$ 로 가장 낮았고, 농업용수로 이용하는 6월까 지 낮은 저수율을 보이다가 7월 이후 집중된 강우로 인 해 유입 유량이 증가하여 8 월부터 10 월까지 저수율이 최대 $80 \%$ 까지 증가한 후 11 월부터 다시 감소하는 패턴 을 보여 강우량과 관개용수 이용에 따른 수위변화가 일 어나는 시기를 기준으로 저수율의 차이를 나타내었다.

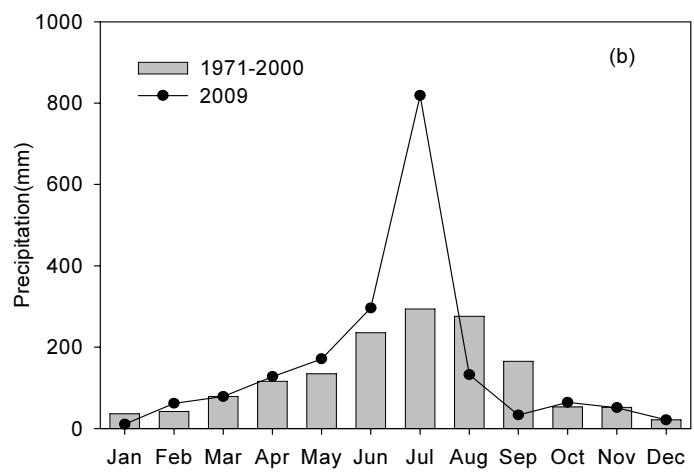

Fig. 3. Annual and monthly variations of Temperature(a) and Precipitation(b) of Junam Reservoir(2009).

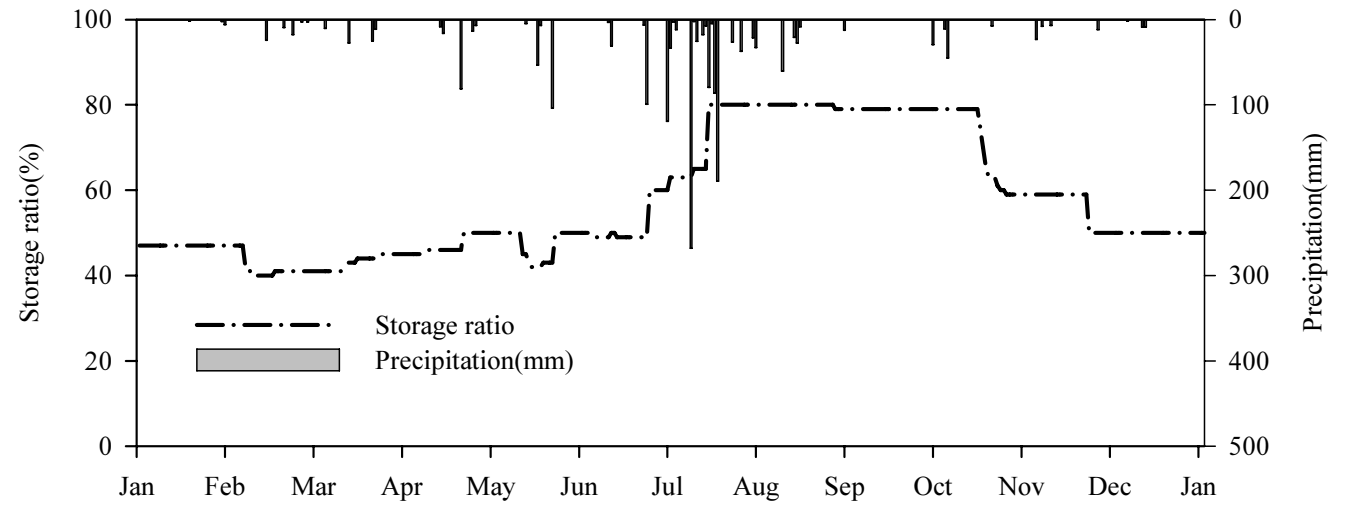

Fig. 4. Monthly changes of Storage ratio and Precipitation of Junam reservoir(2009). 


\section{2. 오염원 및 오염부하량 평가}

수질오염에 영향을 미칠 수 있는 오염원의 발생부 하량과 배출부하량은 전국오염원조사(환경부, 2007) 를 활용하여 수계오염총량관리기술지침(국립환경과 학원, 2007)에 따라 원단위를 산정하였다. 인구에 의 한 생활오염원과 가축사육에 의해 발생되는 축산오염 원, 공장 등 산업시설에서 유출되는 산업계 오염원 등 을 점오염원으로 구분하고, 논, 밭, 임야 등 유역 내 토 지이용으로 인해 발생되는 비점오염원으로 구분하여 Table 1에 나타내었다. 유역 내 생활계 오염원의 경우, 주민등록상 거주인구를 조사하였으며, 주남저수지 유 역의 총 인구는 19,014 명으로 그 중 하수처리 인구는 10,379 명, 하수미처리 인구는 8,635명으로 유역 내 하 수도 보급률은 $54.6 \%$ 인 것으로 조사되었다. 유역 내 축산계 오염원의 경우, 가금 등 기타 분류군이 전체의 $64 \%$ 로 가장 높은 비율을 차지하였으며, 한우, 젖소 등 은 $2 \%$ 내외로 비교적 적게 분포하였다. 비점오염원의 경우, 유역 내 토지 이용 면적 $54.6 \mathrm{~km}^{2}$ 중 임야가 22.0 $\mathrm{km}^{2}$ 로 전체의 $40.3 \%$ 로 차지하였으며, 기타 $17.7 \mathrm{~km}^{2}$ $(32.4 \%)$, 답 $10.1 \mathrm{~km}^{2}(18.6 \%)$, 전 $3.3 \mathrm{~km}^{2}(6.0 \%)$, 대지 $1.5 \mathrm{~km}^{2}(2.7 \%)$ 의 순으로 조사되었다.

본 연구에서 주남저수지 유역의 오염원별 발생부 하량과 기여율을 Table 2에 제시하였다. BOD 발생부 하량은 축산계에 의해 $1,634.3 \mathrm{kgday}^{-1}$ 의 BOD가 발생 하여 전체의 $43 \%$ 로 가장 높은 것으로 나타났고 그 외 생활계와 토지계가 각각 $39 \%, 17 \%$ 순으로 조사되었 다, 총 TN 발생부하량은 $1,163.5 \mathrm{kgday}^{-1}$ 로 토지계와 축산계, 생활계가 $36 \%, 34 \%, 30 \%$ 를 차지하였으며, $\mathrm{TP}$ 발생부하량도 TN과 마찬가지로 축산계가 127.7 $\mathrm{kgday}^{-1}$ 로 전체의 $76 \%$ 를 차지하여 부하량 기여율이 높았고, 생활계와 토지계에서 일부 발생하는 것으로
나타났다.

오염물질은 수체로 직접 유입되기도 하지만, 강우 시 토양층을 통해 비점오염원의 형태로 유입되기도 하며 오염물질별로 각종 처리시설 등을 통해 제거되 는 양이 다르므로 발생량과 배출량은 차이가 있을 수 있다. 따라서 유역 내 발생부하량보다 배출부하량이 수질과 관련된 오염물질의 양적평가로 더 적합할 수 있다(김 등, 2008; 국립환경과학원, 2007). 주남저수 지 유역의 배출부하량은 Table 3 에서와 같이 총 $\mathrm{BOD}$ 배출부하량 $1,458.1 \mathrm{kgday}^{-1}$ 중 생활계가 $50 \%$, 토지계 가 $36 \%$ 를 차지하였고, 총 TN 배출부하량은 $791.8 \mathrm{~kg}$ $\mathrm{day}^{-1}$ 로 토지계와 생활계가 각각 $43 \%$ 를 차지하였다. 총 TP 배출부하량은 $53.4 \mathrm{kgday}^{-1}$ 로 다른 항목과 마찬 가지로 생활계에서 $25.6 \mathrm{kgday}^{-1}$ 로 전체의 $48 \%$ 를 차 지하여 가장 높았고 토지계가 $30 \%$, 축산계가 $22 \%$ 순 으로 나타났다.

우리나라 농업용 저수지 중 23 개 소규모 저수지를 대상으로 유역으로부터 배출되는 부하량을 조사한 결 과, 점오염원에 의한 배출부하량이 $\mathrm{BOD} 29.7 \%, \mathrm{TN}$ $11.3 \%, \mathrm{TP} 16.8 \%$ 로 낮았고 상대적으로 토지 이용형 태와 같은 비점오염원에 의한 배출부하량이 많은 것 으로 보고되고 있다(김 등, 2008). 그러나 본 조사 대 상 호소인 주남저수지의 경우 인구에 의한 생활오염 원과 축산오염원 등 점오염원에 의한 부하량이 높은 것으로 나타났는데(Fig. 5), 이는 수계로 유입되는 덕 천천, 중앙천, 주황천 등 소하천들이 방사상으로 형성 되어 이들 유역에서 발생하는 각종 오염원들이 짧은 거리로 직접 유입되고, 저수지 인근에 시가지가 형성 되면서 유역 면적에 비해 거주 인구수가 증가하고 있 으며, 또한 하수도 보급률이 낮은 것이 원인인 것으로 판단된다.

Table 1. Pollution sources of Junam reservoir

\begin{tabular}{|c|c|c|c|c|c|c|c|c|c|c|c|c|}
\hline \multirow{3}{*}{ category } & \multicolumn{6}{|c|}{ Point pollution source } & \multicolumn{6}{|c|}{ Nonpoint pollution source } \\
\hline & \multirow{2}{*}{ Domestic } & \multicolumn{5}{|c|}{$\begin{array}{c}\text { Livestock } \\
(\%)\end{array}$} & \multicolumn{6}{|c|}{$\begin{array}{c}\text { Land use }\left(\mathrm{km}^{2}\right) \\
(\%)\end{array}$} \\
\hline & & $\begin{array}{l}\text { Korean } \\
\text { cattle }\end{array}$ & $\begin{array}{l}\text { Diary } \\
\text { cattle }\end{array}$ & Pig & Etc. & $\begin{array}{l}\text { Sub } \\
\text { Total }\end{array}$ & Paddy & $\begin{array}{l}\text { Crop } \\
\text { land }\end{array}$ & Forest & Pasture & Etc. & $\begin{array}{c}\text { Sub } \\
\text { Total }\end{array}$ \\
\hline $\begin{array}{c}\text { Junam } \\
\text { Reservoir }\end{array}$ & 19,014 & $\begin{array}{l}435 \\
(1.7)\end{array}$ & $\begin{array}{l}487 \\
(1.6)\end{array}$ & $\begin{array}{l}9,008 \\
(32.3)\end{array}$ & $\begin{array}{l}17,926 \\
(64.4)\end{array}$ & $\begin{array}{c}27,856 \\
(100)\end{array}$ & $\begin{array}{c}3.3 \\
(6.0)\end{array}$ & $\begin{array}{c}10.1 \\
(18.6)\end{array}$ & $\begin{array}{c}22.0 \\
(40.3)\end{array}$ & $\begin{array}{c}1.5 \\
(2.7)\end{array}$ & $\begin{array}{c}17.7 \\
(32.4)\end{array}$ & $\begin{array}{c}54.6 \\
(100)\end{array}$ \\
\hline
\end{tabular}


Table 2. Comparison of BOD, TN, TP generation loads and the ratio

\begin{tabular}{|c|c|c|c|c|c|c|}
\hline & \multicolumn{2}{|c|}{ BOD } & \multicolumn{2}{|c|}{ TN } & \multicolumn{2}{|c|}{$\mathrm{TP}$} \\
\hline & $\operatorname{kgday}^{-1}$ & $\%$ & kgday $^{-1}$ & $\%$ & kgday $^{-1}$ & $\%$ \\
\hline$\overline{\text { Domestic }}$ & 1,463 & 39 & 349.7 & 30 & 21.0 & $\overline{12}$ \\
\hline Livestock & $1,634.3$ & 43 & 401.1 & 34 & 127.7 & 76 \\
\hline Industrial & 73.9 & 2 & 5.0 & 0 & 1.7 & 1 \\
\hline Land use & 628.0 & 17 & 407.8 & 36 & 19.5 & 11 \\
\hline Total & $3,799.2$ & 100 & $1,163.5$ & 100 & 169.9 & 100 \\
\hline
\end{tabular}

Table 3. Comparison of BOD, TN, TP Discharge loads and the ratio

\begin{tabular}{|c|c|c|c|c|c|c|}
\hline & \multicolumn{2}{|c|}{ BOD } & \multicolumn{2}{|c|}{ TN } & \multicolumn{2}{|c|}{$\mathrm{TP}$} \\
\hline & kgday $^{-1}$ & $\%$ & kgday $^{-1}$ & $\%$ & kgday $^{-1}$ & $\%$ \\
\hline Domestic & 731.5 & 50 & 344.9 & 43 & 25.6 & 48 \\
\hline Livestock & 204.3 & 14 & 107.9 & 14 & 11.6 & 22 \\
\hline Industrial & 1.1 & 0 & 0.5 & 0 & 0.1 & 0 \\
\hline Land use & 521.3 & 36 & 338.5 & 43 & 16.2 & 30 \\
\hline Total & $1,458.1$ & 100 & 791.8 & 100 & 169.9 & 100 \\
\hline
\end{tabular}

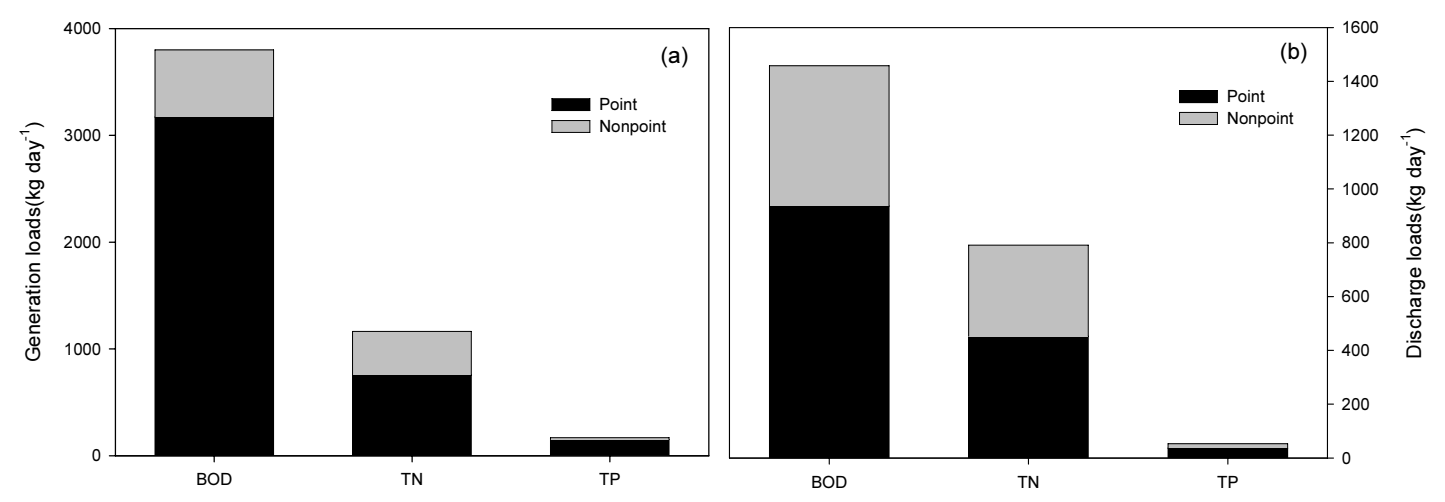

Fig. 5. BOD, TN, TP Generation loads(a) and Discharge loads(b) by point and nonpoint sources.

\section{3. 수질 및 부영양화도}

주남저수지의 수심은 연평균 $0.9 \mathrm{~m}$ 로 얕은 농업용 저수지에 속하며, 월별로는 농업용수를 많이 이용하 는 5 6월의 수심이 가장 낮았고 $(0.5 \mathrm{~m}), 7$ 월에는 강우 량의 증가로 유입 유량이 많아 연중 최대수심 $(1.9 \mathrm{~m})$ 을 보였다. 투명도는 연중 최대 $1.0 \mathrm{~m}$, 최소 $0.5 \mathrm{~m}$ 로 월별, 계절별로 큰 변동은 보이지 않았다(Fig. 6(a)).

식물플랑크톤 생장과 천이를 일으키는 중요한 요 인 중 하나인 수온의 월별 변동을 살펴보면 1 월의 표 층 수온이 $3.4^{\circ} \mathrm{C}$ 로 가장 낮았고 여름철인 7 월부터 상 승하기 시작하여 8 월에 가장 높았고 9월까지 $25^{\circ} \mathrm{C}$ 이 상을 유지하다가 9월 이후 부터 서서히 감소하는 경향
을 보였다. 수온의 영향을 크게 받는 용존산소(DO)의 연평균 농도는 $9.4 \mathrm{mgL}^{-1}\left(7.3 \sim 11.8 \mathrm{mgL}^{-1}\right)$ 로 호소수질 환경기준 $\mathrm{Ia}$ (아주 좋음)에 해당되며, 수온이 낮은 겨 울철(1 3월, 12월)에는 용존산소포화도가 비교적 높 았다. 반면, 수온이 증가하는 5월 이후 용존산소(DO) 는 감소하는 경향을 보이다가 9월에 일시적으로 다시 증가하였는데, 이는 고수온기에 표층에서 증식이 활 발한 남조류 개체수가 증가하면서 이들의 광합성으로 인해 용존산소가 상승한 것으로 보인다(Fig. 6(b)).

수중 유기물 농도의 지표인 화학적산소요구량(COD) 은 조사기간 동안 연평균 $6.8 \mathrm{mgL}^{-1}\left(3.8 \sim 8.7 \mathrm{mgL}^{-1}\right)$ 로 호소수질환경기준 $\mathrm{IV}$ (약간 나쁨)으로, 특히 수체내 식 

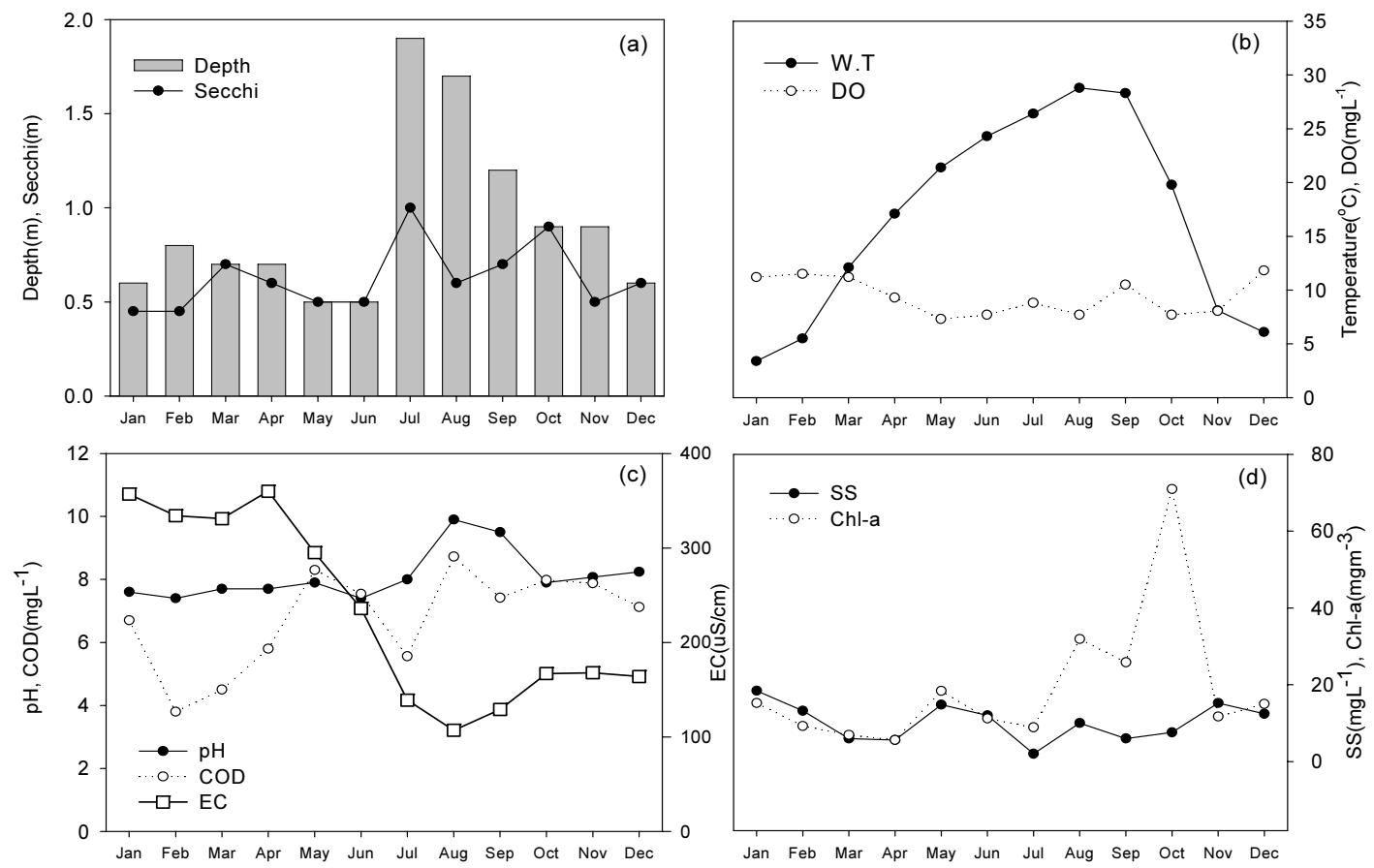

Fig. 6. Monthly changes of water quality in Junam reservoir (2009).

(Depth and Secchi;(a), Water Temperature and Dissolved Oxygen(DO);(b), pH, EC and Chemical Oxygen

Demands(COD);(c), Suspended Solids(SS) and Chlorophyll a;(d))

물플랑크톤 현존량이 높았던 8월과 9월에 높은 것으 로 조사되었다(Table 4). 수중 식물플랑크톤 증식에 직접적인 영향을 받는 수소이온농도 $(\mathrm{pH})$ 는 연평균 8.1(7.4 9.9)로 조사기간 동안 8월과 9월에 각각 9.9, 9.5로 매우 높은 값을 보였다. 이는 고수온기(여름철) 에 표층을 중심으로 증식하는 식물플랑크톤이 수중 용 존탄소 $\left(\mathrm{HCO}_{3}{ }^{-}\right)$를 소모하여 광합성을 함으로써 $\mathrm{pH}$ 농 도가 상승한 것으로 판단된다(박 등, 2005).

전기전도도(EC)의 경우, 연평균 $232.3 \mu \mathrm{Scm}^{-1}$, 월별 로는 107.0 360.0 $\mathrm{HScm}^{-1}$ 의 분포를 보였고, 저수량이 적 은 갈수기 동안(1 5월) 높은 값을 나타내었고 6월부터 감소하기 시작하여 연중 최대 저수량을 보인 8월의 전 기전도도 값이 $107.0 \mu \mathrm{Scm}^{-1}$ 로 가장 낮았다(Fig. 6(c)).

식물플랑크톤 현존량을 나타내는 간접적인 지표인 클로로필 a의 경우, 연평균 $19.2 \mathrm{mg} \mathrm{m}^{-3}(5.6 \sim 70.9 \mathrm{mg}$ $\mathrm{m}^{-3}$ )로 호소수질환경기준 $\mathrm{II}$ (보통)에 속하였다. 월별 변동패턴을 살펴보면 연중 수온이 가장 높았던 8 월에
는 표층에서 남조류 개체수가 증가하여 클로로필 $\mathrm{a}$ 의 농도가 $31.9 \mathrm{mgm}^{-3}$ 까지 증가하였으며, 오히려 수온이 $20{ }^{\circ} \mathrm{C}$ 이하로 낮아진 10 월에 클로로필 $\mathrm{a}$ 의 농도가 70.9 $\mathrm{mgm}^{-3}$ 으로 연중 최고값을 보였는데 이는 남조류와 기 타 편모조류가 혼재하여 우점하면서 클로로필 $\mathrm{a}$ 농도 에 영향을 미친 것으로 판단된다. (Fig. 6(d)).

유기질소를 포함하는 총인(TN)의 경우 연평균 농 도가 $0.757 \mathrm{mgL}^{-1}\left(0.274 \sim 1.842 \mathrm{mgL}^{-1}\right)$ 로 갈수기인 겨 울철과 강우로 인해 외부 오염원 유입이 많은 7월에 농도가 높았다. 수체 내 오염도를 간접적으로 나타내 는 지표 중 무기질소인 암모니아성 질소 $\left(\mathrm{NH}_{3}-\mathrm{N}\right)$ 와 질 산성 질소 $\left(\mathrm{NO}_{3}-\mathrm{N}\right)$ 의 경우, 각각 조사기간 동안 연평 균 농도가 각각 $0.170 \mathrm{mgL}^{-1}, 0.161 \mathrm{mgL}^{-1}$ 로 1 월과 2월 의 농도가 비교적 높은 것으로 나타났다(Fig. 7(a)).

총인(TP)의 경우, 연평균 농도는 $0.032 \mathrm{mgL}^{-1}$ 로 12 월에 수체내 TP농도가 $0.099 \mathrm{mgL}^{-1}$ 을 보여 조사기간 중 가장 높았다. 식물플랑크톤의 제한 인자로 잘 알려 

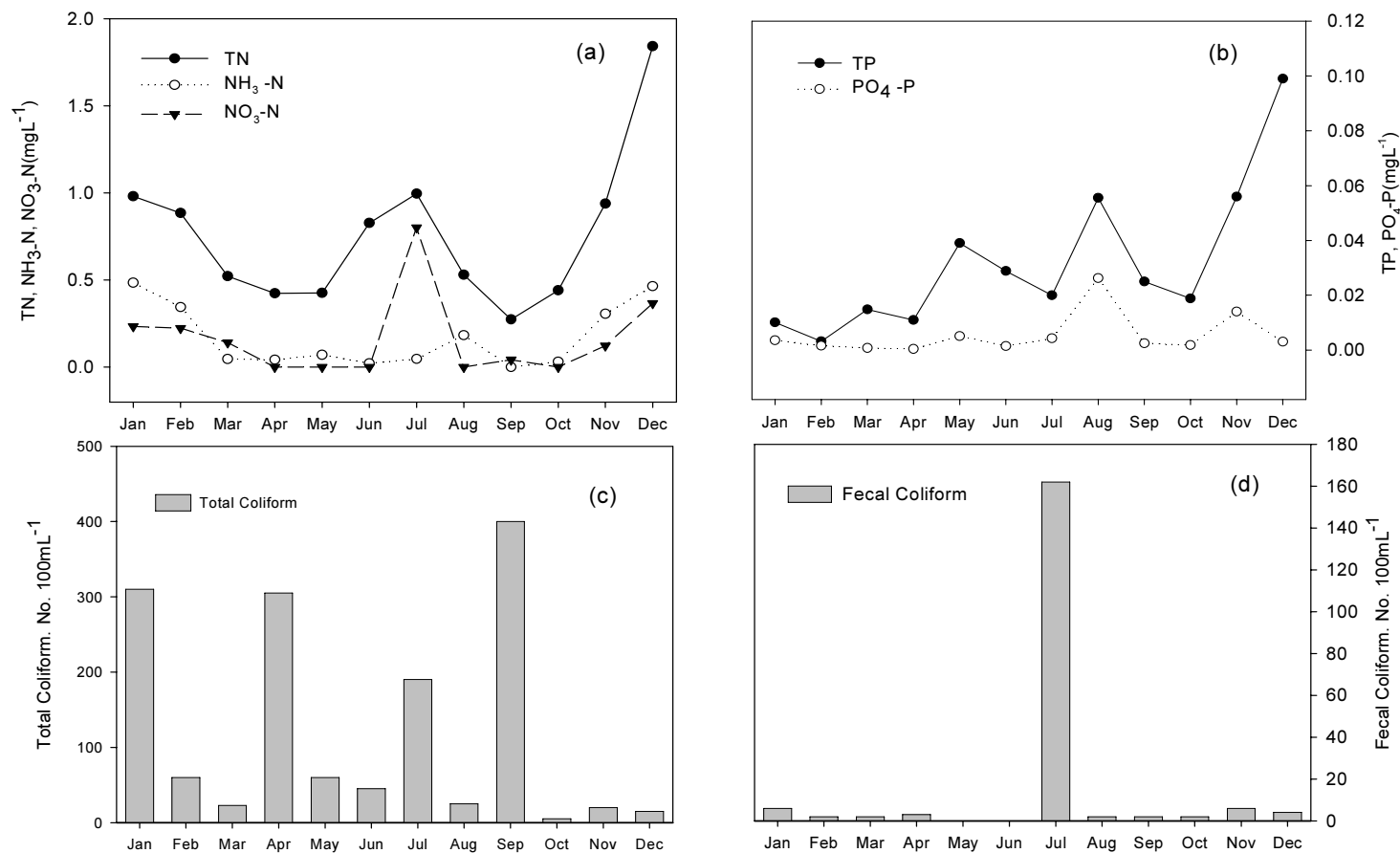

Fig. 7. Monthly changes of water quality at the Junam Reservoir in 2009.

(Total Nitrogen(TN), Ammonium nitrogen $\left(\mathrm{NH}_{3}-\mathrm{N}\right)$ and Nitrate nitrogen $\left(\mathrm{NO}_{3}-\mathrm{N}\right)$; (a), Total Phosphorus(TP) and Phosphate phosphorus $\left(\mathrm{PO}_{4}-\mathrm{P}\right) ;(\mathrm{b})$, Total Coliform;(c), Fecal Coliform;(d))

진 인산염 인( $\left.\mathrm{PO}_{4}-\mathrm{P}\right)$ 의 경우도 총인과 유사한 패턴을 보였으며 연평균농도가 $0.008 \mathrm{mgL}^{-1}$ 로 8 월에 최대농 도 $\left(0.026 \mathrm{mgL}^{-1}\right)$ 로 측정되었다(Fig. 7(b)).

본 연구대상인 주남저수지는 인공호임에도 불구하 고 식물플랑크톤 발생과 관련이 있는 질소/인(TN/TP) 비는 연중 10 97의 범위(연평균 24)로 경남지역에 위 치한 자연늪인 우포늪(9.3 17.2), 정양늪(6.1 16.8), 번개늪(12.0 26.7), 장척호(10.9 55.2)와 유사한 경향 을 보였다. 특히 조사기간 중 남조류가 우점하는 시기 인 8 월, 9 월, 10 월에 질소/인의 비가 15 이하로 총질소 가 제한영양염으로 작용하였으며, 이는 표층의 질소
인의 비가 29 이하일 때 남조류가 우점하고, 수온과 양 $(+)$ 의 상관관계를 가진다(Smith, 1986 ; 김과 김, 2004)는 보고를 잘 반영하였다.

수체 내 분변성 오염 지표인 총대장균군은 $1,4,7$, 9월을 제외하고는 100 No. $100 \mathrm{~mL}^{-1}$ 이하로 낮았으며 연중 호소수질환경기준으로 $\mathrm{Ib}$ (좋음)상태를 유지하 였다. 분원성대장균군 역시 강우로 인해 외부 오염원 의 유입원이 많은 7월에 최대 $162 \mathrm{No.} 100 \mathrm{~mL}^{-1}$ 로 최 고값을 보였으나 그 외 기간에는 $10 \mathrm{No} .100 \mathrm{~mL}^{-1}$ 미 만으로 호소수질환경기준 $\mathrm{Ia}$ (매우 좋음) 상태를 보 여 주남저수지의 분변 오염도는 양호하였다(Fig. 7(c),

Table 4. Lake Standards for the living Environment of Junam Reservoir(2009)

\begin{tabular}{|c|c|c|c|c|c|c|c|c|c|}
\hline & \multirow{2}{*}{$\mathrm{pH}$} & \multirow{2}{*}{$\begin{array}{c}\mathrm{DO} \\
\left(\mathrm{mg} \mathrm{L}^{-1}\right)\end{array}$} & \multirow{2}{*}{$\begin{array}{c}\mathrm{COD} \\
\left(\mathrm{mg} \mathrm{L}^{-1}\right)\end{array}$} & \multirow{2}{*}{$\begin{array}{c}\mathrm{SS} \\
\left(\mathrm{mg} \mathrm{L}^{-1}\right)\end{array}$} & \multirow{2}{*}{$\begin{array}{c}\text { Chl-a } \\
\left(\mathrm{mg} \mathrm{m}^{-3}\right)\end{array}$} & \multirow{2}{*}{$\begin{array}{c}\mathrm{TN} \\
\left(\mathrm{mg} \mathrm{L}^{-1}\right)\end{array}$} & \multirow{2}{*}{$\begin{array}{c}\mathrm{TP} \\
\left(\mathrm{mg} \mathrm{L}^{-1}\right)\end{array}$} & \multicolumn{2}{|c|}{$\begin{array}{l}\text { E-Coliform } \\
\left(\text { No. } 100 \mathrm{~mL}^{-1}\right)\end{array}$} \\
\hline & & & & & & & & Total & Fecal \\
\hline $\begin{array}{l}\text { Junam } \\
\text { reservoir }\end{array}$ & 8.1 & $\begin{array}{c}9.4 \\
\text { I a } \\
\text { (Very good) }\end{array}$ & $\begin{array}{c}6.8 \\
\text { IV } \\
\text { (Fairly Poor) }\end{array}$ & $\begin{array}{c}10.3 \\
\text { (Fair) }\end{array}$ & $\underset{\text { (Fair) }}{19.2}$ & $\begin{array}{c}0.757 \\
\text { IV } \\
\text { (Fairly Poor) }\end{array}$ & $\begin{array}{c}0.032 \\
\text { III } \\
\text { (Fair) }\end{array}$ & $\begin{array}{c}122 \\
\text { I b } \\
\text { (good) }\end{array}$ & $\begin{array}{c}16 \\
\text { I b } \\
\text { (good) }\end{array}$ \\
\hline
\end{tabular}


Fig. 7(d)).

주남저수지의 영양단계를 평가하기 위하여 클로로 필 $\mathrm{a}$ 와 총인을 기준으로 영양상태 지수를 수정 Carlson 지표(TSIm)의 평가 기준에 따라 바꾸어 부영 양화 지수가 40 미만일 경우 빈영양(Oligotrophic), 40 50은 중영양(Mesotrophic), 50 이상일 때 부영양 (Eutrophic)으로 평가하였다. TSIm(Chl)의 경우, 2 4 월, 7 월에는 중영양, 그 외에는 연중 부영양단계로 나 타났다. 그러나 TSIm(TP)의 경우 최저 26에서 최고 69 의 범위로 변화의 폭이 큰 편이나 평균적으로는 연 중 부영양상태를 나타내었다. 월별로는 2 월에 부영양 화도 지수가 26으로 빈영양, 1 월, 3 4월, 7월과 10월 에는 중영양, 그 외 기간에는 부영양상태를 보였다 (Fig. 8).

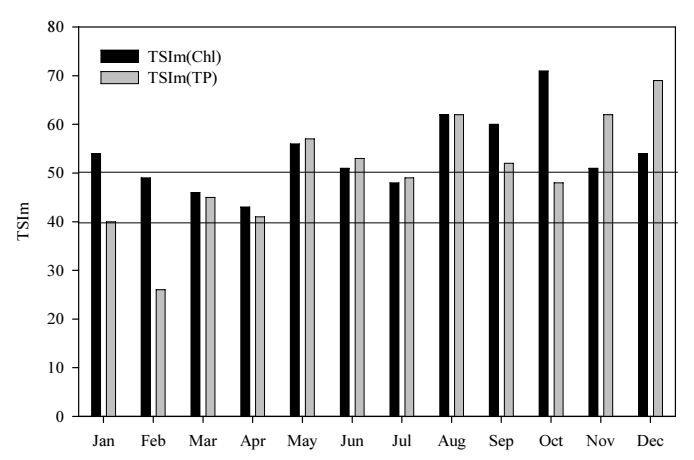

Fig. 8. Monthly changes of TSIm in the Junam reservoir (2009).

\section{4. 식물플랑크톤 분석}

조사기간 동안 주남저수지의 표층수를 대상으로 식물플랑크톤을 정량 분석한 결과, 총 76 종이 동정되 었으며, 분류군별로는 녹조류 33종(43.4\%), 규조류 27 종(35.5\%), 남조류 8종(10.5\%), 기타 편모조류 8종 (10.5\%)으로 구성되었다. 월별 출현 종수는 3 월에 8 종으로 가장 적었으며, 5 월에 가장 많은 32 종이 출현 하였다(Fig. 9).

조사기간 동안 식물플랑크톤의 현존량은 평균 2,470 cells mL $\mathrm{mL}^{-1}$ 로 나타났으며 녹조류와 편모조류가 주로 우점하였던 1 월부터 4 월까지는 전체 식물플랑크 톤 현존량이 500 cells $\mathrm{mL}^{-11}$ 미만으로 낮게 조사되었 다. 수온이 $25^{\circ} \mathrm{C}$ 이상으로 상승하기 시작한 7 월부터
강우로 인한 유입량이 많아지면서 수체내 영양염의 농도가 증가하였고, 주남저수지와 같이 수심이 얕은 호소에서는 남조류 개체수가 급격하게 증가할 수 있 는 호조건이 형성되어 8 월부터 10 월까지 식물플랑크 톤 전체 현존량이 5,000 cells $\mathrm{mL}^{-1}$ 을 초과하였고, 분 류군별로는 남조류의 구성비가 $60 \%$ 이상을 차지하였 다. 가을철인 10 월에는 수온이 감소하면서 편모조류, 녹조류, 남조류가 혼재하여 조사기간 중 식물플랑크 톤 현존량이 가장 높았으며, 클로로필 a 농도 또한 최 고값을 보였다. 11 월과 12월에는 편모조류가 우점하 면서 식물플랑크톤 현존량이 감소하는 것으로 조사되 었다(Fig. 9, Fig. 10).

우점종의 월별 변화는 Table 5 에 나타내었으며, 봄 철에는 편모조류인 Cryptomonas spp.와 녹조류인 Crucigenia spp.가 주로 우점하였고 수온이 증가하기 시작한 6월부터 남조류가 출현하여 7월부터 초가을에 접어드는 10 월까지 고수온기에 생장이 활발한 남조류 인 Microcystis aeruginosa, Anabaena spp. 등이 우점 종으로 출현하였다. 겨울철인 11 12월에는 편모조류 인 Dinobryon divergens 과 Cryptomonas spp.이 우점 하는 경향을 보였다.

주남저수지의 식물플랑크톤 속별 계절적 변화는 과 거 조사결과(조와 곽, 1999)와 유사한 경향을 보였다. '97년 10월부터 '99년 3월까지 조사된 결과에서는 봄 과 가을에 녹조류인 Crucigenia spp. 및 Scenedesmus spp., 여름에는 남조류 Anabaena spp., Oscillatoria spp., Microcystis spp., Phormidium spp. 등이 주로 출 현하였고, 겨울에는 Synura spp. 등 기타 편모조류 순 으로 천이되는 양상을 보여 본 연구 결과와 속천이 패 턴은 유사하게 나타났으나 종 구성에 있어서는 다소 차이가 있는 것으로 나타났다. 이와 같이 주남저수지 의 식물플랑크톤 계절적 변화는 국내 인공호소의 일 반적인 패턴인 봄과 가을에는 규조류와 편모조류, 여 름에는 녹조류와 남조류가 우점하는 온대지역의 일반 적인 천이 양상과 다른 양상을 나타내었다. 또한 인접 지역(창녕군)에 위치하는 우리나라 대표적인 자연늪 인 우포늪에서의 계절별 식물플랑크톤 천이양상에서 도 규조류의 상대적인 구성비는 높았으나, 우점종으 로 출현하지 않는 특성을 보였다. 우포늪의 클로로필 $\mathrm{a}$ 농도와 식물플랑크톤 현존량 변화 역시 주남저수지 


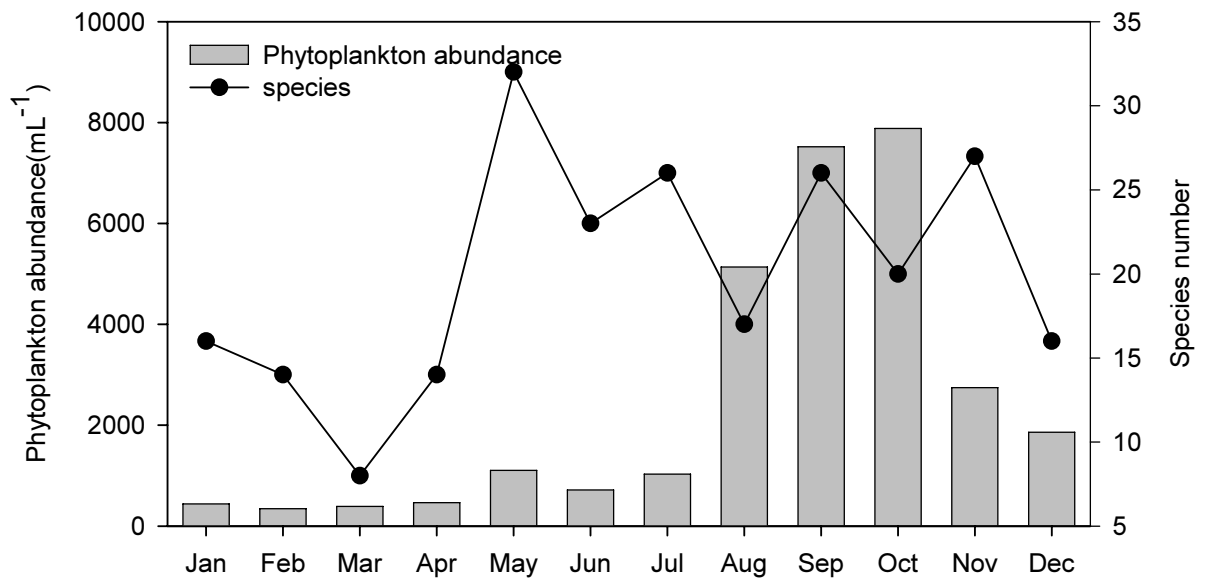

Fig. 9. Monthly variations of phytoplankton abundance and the number of species in Junam reservoir(2009).

와 유사하게 1 월부터 5 월까지는 매우 낮은 분포를 보 이다가 7월에 남조류가 출현하면서 클로로필 a 농도 와 현존량이 증가하기 시작하여 10 월과 11 월까지 최 고치를 보인 후 감소하는 경향을 보였는데(김, 2001), 이는 수심이 얕은 전형적인 강 배후 습지의 특징으로 기상과 수리수문의 영향을 크게 받아 식물플랑크톤 출현 양상에도 영향을 미치는 것으로 사료된다.

주남저수지에 대한 식물플랑크톤 군집구조를 분석 하기 위해 월별 종 다양도지수( $\left.\mathrm{H}^{\prime}\right)$ 와 우점도지수(DI) 를 비교 해 본 결과는 Fig. 11 과 같다. 종 다양도 지수 $\left(\mathrm{H}^{\prime}\right)$ 는 $1.20 \sim 2.71$ 의 범위로서 조사기간 중 녹조류가 주로 출현한 5월에 종 다양도 지수가 2.71 로 가장 높 았고, 12 월에 1.20 으로 가장 낮게 나타났으며, 남조류 가 주로 우점하였던 8,9 월에도 종 다양도가 1.59 , 0.61 로 비교적 낮았다. 우점도 지수(DI)는 $0.09 \sim 0.48$ 의 범위를 보였고 월별로는 편모조류가 우점하였던 3 월과 11 월에 우점도 지수가 각각 $0.43,0.48$ 로 조사기 간 중 높게 나타났고, 5 월에 우점도 지수가 0.09 로 가 장 낮았다. 이와 같이 주남저수지의 월별 식물플랑크 톤 군집구조를 분석한 결과 종 다양도와 우점도 지수 는 역의 상관관계를 보였으며, 녹조류가 주로 우점하 는 시기에는 종 다양도 지수는 높고 우점도는 낮게 나 타난 반면, 편모조류와 남조류가 주로 출현할 때는 종 다양도는 낮고, 우점도는 높은 것으로 조사되었다 (Fig. 12).

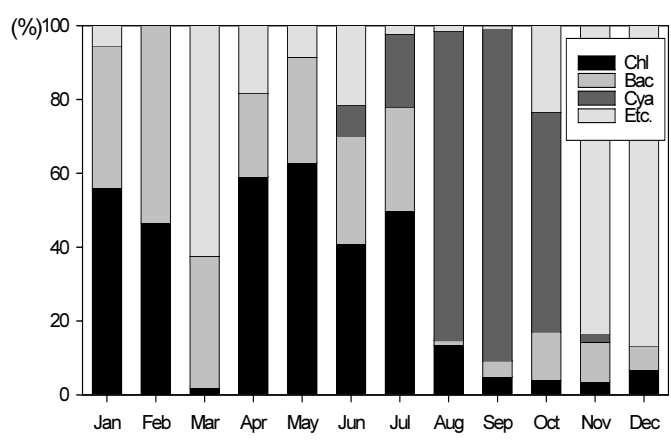

Fig. 10. Monthly variations of relative percentage of different algal group during the survey period in Junam reservoir. (Chl;Chlorophycea, Bac;Bacillariophyceae, Cya;Cyanophycea, Etc.;Crysophyta, Euglenaphyta, Dinophyta and Cryptophyta)

Table 5. Dominant species of phytoplankton in the Juman reservoir(2009)

\begin{tabular}{cc}
\hline & Dominant species \\
\hline \hline Jan & Chlamydomonas spp. \\
\hline Feb & Ankistrodesmus falcatus \\
\hline Mar & Cryptomonas spp. \\
\hline Apr & Chlamydomonas spp. \\
\hline May & Crucigenia spp. \\
\hline Jun & Cyclotella spp. \\
\hline Jul & Anabaena spp. \\
\hline Aug & Microcystis aeruginosa \\
\hline Sep & Anabaena spp. \\
\hline Oct & Microcystis spp. \\
\hline Nov & Dinobryon divergens \\
\hline Dec & Cryptomonas spp. \\
\hline
\end{tabular}




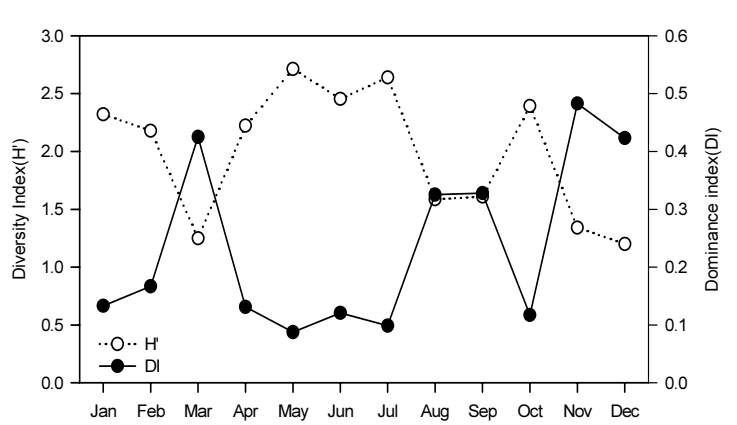

Fig. 11. Monthly variations of phytoplankton Diversity index(H') and Dominance index(DI).

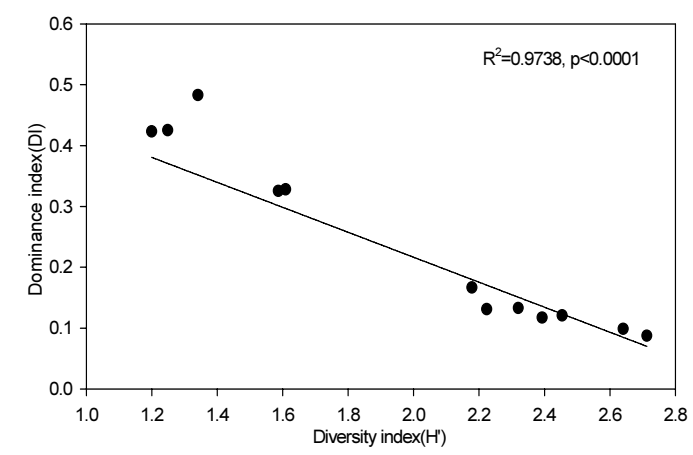

Fig. 12. Correlations between Diversity index $\left(\mathrm{H}^{\prime}\right)$ and Dominance index(DI) in the Junam reservoir.

\section{4. 결 론}

본 연구에서는 호소환경 관리대책 마련을 위한 장 기 기초 자료 확보를 목적으로 주남저수지를 대상으 로 유역 내 오염원 및 부하량, 연간 수질변동에 따른 식물플랑크톤 군집 동태를 조사하였다. 주남저수지의 기상 및 수리수문 분석결과, 조사기간 동안 연간 강우 량은 $1,868.9 \mathrm{~mm}$ 로 평년 $(1,506.7 \mathrm{~mm})$ 에 비해 $20 \%$ 가량 증가하였으며 평균 저수율은 $57.3 \%$ 를 유지하였다. 유 역 내 오염부하량은 발생부하량의 경우, 축산계>생활 계>토지계>산업계 순으로 점오염원의 비율이 높게 차지하였고, 배출부하량은 생활계>토지계>축산계> 산업계 순으로 점, 비점오염원 모두 다량 배출되는 것 으로 나타났다.

주남저수지의 수질변화는 유기물 항목인 $\mathrm{COD}$ 는 연 평균 $6.8 \mathrm{mgL}^{-1}$ 으로 호소수질환경기준 $\mathrm{IV}$ (약간 나쁨) 에 해당하며, 특히 수체 내 식물플랑크톤 현존량이 높
았던 8월과 9월에 비교적 높은 농도를 보였다. TN, TP 는 연평균 $0.757 \mathrm{mgL}^{-1}, 0.032 \mathrm{mgL}^{-1}$ 을 보였으며, 특히 강우기인 7 8월에 외부 오염원의 유입이 증가하여 호 소가 부영양화되고 여름과 가을철 조류 개체수 증가 에 영향을 미치는 것으로 보인다. 수정 Carlson's 지수 를 이용하여 주남저수지 영양상태를 평가한 결과, TSIm (Chl-a)가 2 4월, 7월을 제외하고 연중 부영양상태가 지 속되어 전형적인 얕은 호소의 특성을 보여주었다.

주남저수지에서 조사된 식물플랑크톤은 총 76 종으 로 분류군별로 녹조류 33 종(43.4\%), 규조류 27종(35.5\%), 남조류 8 종 $(10.5 \%)$, 기타 편모조류 8 종 $(10.5 \%)$ 으로 구성되었다. 식물플랑크톤의 현존량은 봄철인 3 월에 392 cells mL L $^{-1}$ 로 가장 적게 나왔으며, 가을철인 10 월에 남조류와 규조류가 혼재하여 7,884 cells mL $\mathrm{mL}^{-1}$ 로 가장 높 았다. 우점종의 계절별 천이양상은 수온이 낮은 겨울철 과 초봄인 1 월부터 5 월까지 녹조류인 Chlamydomonas spp., Ankistrodesmus falcatus, Crucigenia spp.가 주 로 우점하였다. 수온이 증가하기 시작한 6월부터 남조 류가 출현하기 시작하여 여름철인 7월부터 9월까지 유해남조류인 Microcystis aeruginosa, Anabaena spp. 등이 우점하였고, 그 외 규조류 Cyclotella spp., Aulacoseira granulata, 녹조류 Pediastrum tetras 등 이 출현하는 것으로 나타났다. 10 월부터 12 월까지는 편모조류인 Rhodomonas spp., Dinobryon divergens, Cryptomonas spp.이 우점하였다. 주남저수지에 대한 식물플랑크톤 군집분석결과, 다양도 지수는 1.20 2.71 의 범위로서 조사기간 중 녹조류가 주로 출현한 5 월의 다양도가 높은 것으로 나타났다. 우점도 지수는 $0.09 \sim 0.48$ 의 범위로 3 월과 11 월의 우점도가 높은 것 으로 조사되었다.

이상의 결과로부터 주남저수지의 수질은 얕은 수 심으로 인해 유역 내 오염원의 분포, 수리수문 등의 요 인에 의해 크게 영향을 받으며, 이러한 물리적인 요인 이 수체 내 영양염의 농도를 증가시키고 1 차생산자인 식물플랑크톤 군집변화와 부영양화도를 일으키는 직 접적인 원인으로 작용하는 것으로 보인다. 따라서 구 조적으로 인공호이나 생태학적 가치가 높은 자연 습 지의 기능이 증가되고 있는 주남저수지의 지속적인 수질 및 생태계 관리를 위해서는 오염원, 수리수문, 수 질뿐만 아니라 동식플랑크톤, 수생식물 등 다양한 생 
물상들에 대한 종합적인 연구가 장기적으로 수행되어 야 할 것으로 판단된다.

\section{참 고 문 헌}

국립환경과학원, 2007, 수계오염총량관리지침.

기상청, 2009, http://www.kma.go.kr.

김숙찬, 김한순, 2004 , 영천댐의 식물플랑크톤 군집과 환 경요인의 동태, Algae, 19(3), 227-234.

김원재, 최의소, 1996 , 국내의 부영양화 지수 활용에 관 한 연구, 정기학술발표회논문집, 한국수질보전학회, 11-15.

김종구, 오승철, 2007 , 군산지역 저수지의 수질특성 및 부영양화 평가, 한국환경과학회지, 16(3), 357-367.

김한순. 2001, 우포늪과 목포늪의 식물플랑크톤 군집의 계절적 변동, 한국육수학회지, 34(2), 90-97.

김호섭, 황순진, 공동수, 2007 , 부영양 저수지에서 남조 류의 발달과 천이 및 영향요인, 한국하천호수학회 지, 40(1), 121-129.

김호섭, 최은미, 박주현, 황하선, 김범철, 공동수, 황순진, 2008 , 농업용 저수지 수질과 경험적 인자들과의 관 계, 한국물환경학회지, 24(3), 333-339.

김호섭, 황순진, 2004, 얕은 부영양 저수지의 육수학적 특성-계절에 따른 수질변화, 한국육수학회지, 37(2), 180-192.

박시섭, 1995 , 주남저수지 일대의 담수조류에 관한 연구, 석사학위논문, 경남대학교.

박지은, 이상돈, 2009, 주남저수지에 도래하는 쇠기러기 의 PVA에 의한 생존확률 추정연구, 환경영향평가, 18(5), 583-299.

박혜경, 이현주, 김은경, 정동일, 2005 , 팔당호 조류발생 특성 및 수질환경인자의 통계적 분석, 한국물환경학 회지, 21(6), 584-594.

서정관, 유재정, 이재정, 양상용, 정익교, 2003 , 운문호의 식물플랑크톤 군집동태와 영양단계 평가, Algae, 18(2), 135-143.

양운진, 2005 , 주남저수지 자정작용에 관현 연구, 경남대 학교 환경문제연구소 환경연구, $28,73-80$.

윤춘경, 이새봄, 정광욱, 한정윤, 2007 , 농업용저수지 유 역의 토지이용과 수질항목간의 상관관계 분석, 한국 물환경학회지, 40(1), 31-39.

이의행, 안광국, 2009 , 철새도래지인 주남저수지의 계절 적 수질변동, 한국하천호수학회지, 42(1), 9-18.

이호원, 이상명, 강현무, 박시섭, 1997 , 주남저수지산 인 편성 황갈조류에 관한 연구, 경남대학교 연구논문 집, 20, 37-47.
이호원, 이상명, 이진우, 박시섭, 강현무, 조현아, 1994, 사연 및 동판저수지의 식물성 플랑크톤에 관한 연 구, 경남대학교 환경문제연구소 환경연구, 경남대학 교 연구논문집, 7, 223-233.

이호원, 이상명, 이진우, 박시섭, 강현무, 1994, 산남저수 지와 대암호의 식물성 플랑크톤에 관한 연구, 경남 대학교 연구논문집, 16, 53-61.

전지홍, 윤춘경, 함종화, 김호일, 황순진, 2002 , 농업용저 수지의 물리적 인자가 수질에 미치는 영향, 한국육 수학회지, 35(1), 28-35.

정준, 1993, 한국담수조류도감, 아카데미 서적.

조경제, 곽승국, 1999 , 주천강-주남저수지의 담수조류, 춘계학술발표회논문집, 한국생태학회, 82.

한국 농촌공사, 2009, http://www.ekr.or.kr.

함규황, 김창숙, 김인규, 1999 , 최근 10년('89-'98)간 주 남저수지 조류의 종수 및 개체수 변동에 관한 연구. 한국조류학회지, 6(2), 127-132.

함규황, 손성원, 1998 , 경상남도 창녕군 우포늪과 창원시 주남저수지 일대의 조류분포, 경남대학교 연구논문 집, 261-273.

환경부, 2001 , 호소환경조사지침.

환경부, 2007, 전국 오염원 조사 보고서.

Aizaki, M., Otsuki, A., Fukushima, T., Kawai, T., Hosomi, M., Muraoka, K., 1981, Application of modified Calson's Trophic State Index to Japanese and its relationships to other parameters related to trophic stage, Res. Rep. Natl. Inst. Environ. Stud, 23, 13-31.

Eaton, A. D., Clesceri, L. S, Rice, E. W., Greenberg, A. E., Franson, 2005, Standard Methods for the Examination of Water \& Wastewater, 21th ed., American Public Heath Association.

Guillermo, C., 2009, The use of phytoplankton patterns of diversity for algal bloom management, Limnologica, 39, 200-208.

Masaru, A., Teru, I., Kozo, I., Hideo, K., Shigeru, K., Hiromu, K., Eiji, T., Kohei, T., Minoru, H., Hiroyuki, H., Takaaki, Y., 1977, Illustrations of the Japanese fresh water algae.

Shannon, C. E., Weaver, W., 1963, The mathematical theory of communication. Illinois Univ. Press, London.

Simpson, E. H., 1949, Measurement of Diversity, Nature, 163.

Smith, W. H., 1986, Prediction the proportion of blue-green algae in lake phytoplankton, Can. J. Fish. Aquatic Sci., 43, 148-153. 